\title{
Climate change impacts on rain-fed and irrigated rice yield in Malawi
}

\author{
Daccache, A. ${ }^{1}$, Sataya, W. ${ }^{2}$ and Knox, J.W. ${ }^{1 *}$ \\ ${ }^{1}$ Cranfield Water Science Institute, Cranfield University, Bedfordshire, MK43 OAL, UK \\ ${ }^{2}$ Department of Irrigation, Ministry of Agriculture, Government of Malawi, Malawi
}

\begin{abstract}
There is extensive scientific evidence on climate impacts and adaptation in rice (Oryza sativa L.) but the majority relates to production in south Asia and China. Only a handful of studies have been conducted in Sub-Saharan Africa and none in Malawi. In this paper, the climate impacts on rain-fed and irrigated rice yield have been assessed by combining the downscaled outputs from an ensemble of general circulation models (GCM) (HADCM3, INCM3 and IPCM4) with data from the LARS-WG weather generator to drive the CERES-Rice crop model. This was calibrated and validated using 10 years (20012010) field data from three rice schemes to simulate the baseline (1961-90) yield $\left(\mathrm{t} \mathrm{ha} \mathrm{a}^{-1}\right)$ and then model future yield changes for selected (B1 and A2) emissions scenarios for the 2050s. Although relatively small increases in average yield were projected $(+8 \%$ and $+5 \%$ for rainfed and irrigated rice, respectively) there was large uncertainty $(-10 \%$ to $+20 \%$ yield change) when considering different GCMs and emission scenario. Farmer responses to cope with the projected impacts include both autonomous and planned adaptation strategies, such as modifying planting dates to maximise crop growth calendars and available soil moisture, increased use of on-farm water conservation measures and land levelling to improve water efficiency in rice schemes dependent on surface irrigation.
\end{abstract} Keywords: Africa; agriculture; CERES-Rice; crop model, irrigation; weather generator.

\section{Introduction}

Among the major cereals grown globally, rice is the most rapidly growing food source in Sub-Saharan Africa (SSA). In the last 40 years, rice consumption in SSA has increased annually at an average rate of 4.52\%, higher than production (3.23\%) and population growth (2.9\%) (Sié et al., 2012). In Malawi, rice (Oryza sativa L.) is the second most important cereal crop grown by smallholder farmers under rainfed ( $85 \%$ of the total rice area) and irrigated conditions (Mzengeza, 2010). Approximately 60,000 hectares are cultivated each year (GoM, 2008) mostly along the lake shores in north and central Malawi and in southern districts of Zomba, Machinga, Phalombe, Chikwawa and Nsanje (Figure 1). In 2010, mean national productivity was $1.86 \mathrm{t} \mathrm{ha}^{-1}$ compared to $2.2 \mathrm{t} \mathrm{ha}^{-1}$ for East Africa and $4.36 \mathrm{t} \mathrm{ha}^{-1}$ for the rest of 
the world (FAOSTAT, 2012). Such low levels of productivity are largely attributed to small farm sizes, the use of low yielding local varieties, unreliable rainfall and poor crop management (Kanyika et al., 2007). However, productivity has potential to reach 4 to $6 \mathrm{tha}^{-1}$ under rain-fed and irrigated systems (Sistani et al., 1998). Any improvements in yield would have major social and economic benefits for farmers and rural communities and would support national policies for food security.

Despite advances in crop management, such as improved varieties, mechanisation and advanced irrigation technologies, climate remains one of the key factors influencing crop productivity. In Africa, the increased frequency of droughts and floods expected as a consequence of climate change could lead to lower crop yields and/or in some regions total crop failure (Christensen, 2007). Many studies have concluded that Africa is one of the most vulnerable continents to climate change and yield variability (Wheeler and Kay, 2010; Boko et al., 2007). Cooper et al. (2008) reported that rainfall reduction is likely to have a more substantial impact than temperature increases on African yields under current low input agricultural practice. Thornton et al. (2009) projected a fall in African crop yields of -10 to $-20 \%$ by the 2050s with small-scale farmers being most impacted. This poses a major challenge in Africa considering most of its population is dependent on agriculture with one third already at risk from widespread hunger and malnutrition (Slingo et al., 2005).

Although there has been a steady increase in evidence published in the scientific literature on climate change impacts on rice productivity since the early work by Bachelet et al (1994), Matthews et al. (1997) and others, surprisingly only three scientific studies exist for Sub-Saharan Africa (Knox et al., 2012) and none for Malawi. This paper sets out to provide the first preliminary investigation of the impacts of climate change on rain-fed and irrigated rice in Malawi, a country where rice is one of the most important food crops for sustaining rural livelihoods. The analysis also provides an important contribution to the limited evidence base on climate impacts in Africa more generally and will support programmes to promote adaptation policies for sustainable agricultural development.

\section{Materials and methods}

In this study the impact assessment involved a number of stages. Firstly, the impacts of climate change on rain-fed and irrigated rice yield were assessed using CERES-Rice, a biophysical crop model 
embedded within the DSSAT (Decision Support System for Agro-technology Transfer) program (Jones et al., 2003). Using 10 years (2001-2010) independent field data from three rice schemes in northern Malawi, the CERES-Rice model was first parameterised and calibrated using five years data; then validated using the other 5 years independent data. Statistical tests were used to assess model performance and goodness of fit. The modelled baseline (1961-1990) yield $\left(\mathrm{t} \mathrm{ha}^{-1}\right)$ was then compared against simulated yields for the 2050s. Future simulations were based on two SRES emissions scenario, downscaled data from three general circulation models (GCM) (HADCM3, INCM3 and IPCM4) available from the IPCC-AR4 database (IPCC, 2013) and synthetic climate data derived from the LARS-WG weather generator (Semenov and Stratonovitch, 2010). Finally, the impacts of GCM uncertainty and crop model sensitivity to selected climate parameters were evaluated. A brief description of the case study area and each stage in the methodology is given below.

\subsection{Study area}

Malawi has a sub-tropical climate, which is very dry in summer and strongly seasonal. The warm-wet season typically lasts from November to April, during which $95 \%$ of annual precipitation occurs (Figure 2a). Average annual reference evapotranspiration (ETo) is $1600 \mathrm{~mm}$, with peak rates of $5 \mathrm{~mm} \mathrm{day}^{-1}$ occurring between September and October (Figure 2b). Transplanting and harvest dates for a rainy season crop vary depending on the onset of rains. Generally, farmers are advised to prepare fields in time so that they can plant once adequate rains arrive (normally between January and mid-February). Under irrigated conditions ( $c v$. Pusa 33) water is applied to maintain a flooded depth of $50 \mathrm{~mm}$ immediately after transplanting. Fields are then drained 10 days before harvest (towards the end of November). In the study area, soil textures ranged from sandy clay loam to heavy clays, but clay loam dominates with a clay content ranging from 35 to $45 \%$ which is suitable for rice production. Further details on each of the three schemes included in this study (highlighted in Figure 1) and their soil characteristics are given in Table 1.

\subsection{Climate change datasets and emissions scenarios}

Using the LARS-WG weather generator, the monthly outputs from three contrasting GCMs (HADCM3, INCM3 and IPCM4) were downscaled to the study area to generate a series of future daily time-step climate datasets for input into the CERES-Rice model. The LARS-WG produces a synthetic time series 
for minimum and maximum temperature, precipitation and solar radiation. It uses observed daily weather data to compute a set of parameters to generate the probability distribution for weather variables and their correlations. These parameters are then used to generate a synthetic time series by randomly selecting values from the appropriate distribution. The parameters for each distribution generated by the LARS-WG were then perturbed with the predicted changes in climate derived from each GCM to produce a set of future daily climate datasets for Karonga.

There are inherent uncertainties in climate projections generated by GCMs (Meehl et al., 2007) caused by an incomplete understanding of the complex earth system processes, and their imperfect representation in climate models combined with uncertainty in future man-made emissions. For example, Aggarwal and Mall (2002) estimated that the impact of climate change on rice yield in India could be biased by up to $32 \%$ by uncertainty caused by the climate change scenario, the level of management and crop model used for yield simulation. To assess GCM uncertainty, the projections in this study were taken from the three GCMs (HADCM3, IPCM4 and INCM3) selected on the basis of how each differed in their projected future changes in precipitation due to the importance of rainfall for crop production in Africa. It was also important that each GCM could provide equivalent data relating to the same emissions scenario. For each GCM, two future weather datasets were generated; one corresponding to a low emission (B1), the other for a high emission (A2) scenario. Scenario data for these were derived from the Special Report on Emission Scenarios (SRES) developed by the IPCC (Nakicenovic et al., 2000). The $\mathrm{B} 1$ scenario has the lowest atmospheric $\mathrm{CO}_{2}$ concentration, reflecting efforts to control $\mathrm{CO}_{2}$ emissions principally through the introduction of clean and resource-efficient technologies. In contrast, the A2 scenario reflects a divided world with an increasing population, regionally oriented economic development and one of the highest atmospheric $\mathrm{CO}_{2}$ concentrations. The baseline (330 ppmv) and future atmospheric $\mathrm{CO}_{2}$ concentrations were set to match those reported in the literature (Nakicenovic et al., 2000).

Using a multi-model ensemble approach provides a valuable range of possible future changes and has been used in previous studies (e.g. Fisher et al., 2005; Lobell et al., 2008). Projected precipitation and average temperature changes for the 2050s constructed from the three GCMs for Karonga are shown in Figure 3. Although modelling uncertainty has been partially addressed by using multi-ensemble 
projections, these GCMs cannot reliably predict changes in extreme events such as the frequency of droughts and storms which could also affect productivity more than any underlying long-term changes in average conditions (Bachelet et al., 1994). For rainfall, the HADCM3 projects a decrease of about $15 \%$ for both scenario (B1 and A2) whilst the INCM3 projects an increase of between $+9 \%$ (B1) and $+28 \%$ (A2). In contrast, the IPCM4 projects almost negligible change ( $-0.1 \%$ for $\mathrm{B} 1)$ to a marginal increase ( $+5.3 \%$ for A2). However, all three GCMs project significant changes in monthly distribution of rainfall, predicting an increase in total rainfall for October, February and May and a decrease in December and January. These differences have important implications on simulated yield and their inter-annual variation. For temperature, the GCMs project an increase in mean air temperature of between 1.5 and $2.5^{\circ} \mathrm{C}$ depending on emission scenario. For both emissions scenarios, the highest projected increase is for June $\left(2.2^{\circ} \mathrm{C}\right.$ and $\left.2.6^{\circ} \mathrm{C}\right)$ and lowest for August $\left(1.5^{\circ} \mathrm{C}\right)$ and February $\left(2.1^{\circ} \mathrm{C}\right)$ for the B1 and A2 scenarios, respectively (Figure 3). This confirms that the weather at Karonga is very likely to experience warming across all seasons with changes in both amount and seasonal timing of rainfall, with consequent impacts on crop growth and development.

\subsection{Modelling rice yield}

For simulating crop yield, the CERES-Rice model, embedded within the DSSAT program (Jones et al., 2003) was used. A brief description of CERES-Rice is given below, but readers interested in a detailed review are referred to Ritchie et al. (1986) and Singh et al. (1993). The CERES-Rice model has been used extensively by researchers in a number of country and regional scale studies to estimate climate impacts on rice productivity (e.g. Lal et al., 1998; Yao et al. 2007), but there are nevertheless no studies reported for Africa. The model can actively simulate canopy response to temperature and radiation changes and incorporates the effects of changes in atmospheric $\mathrm{CO}_{2}$ concentration on crop growth. The CERES-Rice model simulates the daily growth and development of the crop using information on local climate, soil, agronomic management and cultivar. The model is divided into four sub-models focusing on (i) phenological development, (ii) biomass formation and partitioning, (iii) soil water and, (iv) nitrogen balances. Phenological development is controlled by cumulative temperature whilst the growth rate is calculated as the product of absorbed radiation, which is a function of leaf area, using a constant ratio of dry matter yield per unit radiation absorbed. 
Using values from the published scientific literature together with field data from each of the three rice schemes (Table 2), the CERES-Rice model was first parameterised and then calibrated using 5 years (2001-2005) data. Calibration consisted of identifying the appropriate genotype specific, referred by Singh et al. (1994) as "genetic coefficients" that best matched the observed data. The genetic coefficients for Pusa 33 and Kilombero were obtained from the Lifuwu Research Station in Malawi (where available) or derived using a 'trial and error' method (Table 3). The parameterised CERES-Rice model was then used to simulate annual yield for the baseline (1961-1990) using recorded historical weather data for Karonga weather station. The model was re-run for each emissions scenario using the same crop and soil files but replacing the historical data for Karonga with the LARS-WG generated future climate datasets. For each simulation year, the model outputs on yield $\left(\mathrm{t} \mathrm{ha}^{-1}\right)$ were extracted and statistically analysed.

\subsection{CERES-Rice model validation}

Before simulating yield under a 'changed' climate, it was important to ensure that the CERES-Rice model could accurately recreate observed variations in historical yield (Figure 4). Following model parameterisation and calibration, the model was validated using 5 years (2006-2010) independent data, and a linear correlation between the simulated and observed yields completed (Figure 5). Visually, this shows that rainfed yields were, as expected, marginally lower irrigated yields, and that the CERES-Rice simulated yields were in most cases slightly higher than observed yields. Statistical analyses using mean, standard deviation, mean bias error (MBE), root mean squared error (RMSE) and the Student $t$ statistic were then used to test the statistical significance of the model validation and goodness of fit (Table 4). The following equations for RMSE and MBE were used:

$$
\begin{aligned}
& \mathrm{RMSE}=\sqrt{\sum_{\mathrm{i}=1}^{\mathrm{n}} \frac{(S i-O b)^{2}}{\mathrm{n}}} \\
& \mathrm{MBE}=\sum_{i=1}^{n} \frac{(S i-O b)}{n}=
\end{aligned}
$$

Where $n$ is number of paired observations, $S i$ and $O b$ are the simulated and observed values, respectively, at the $i$-th observation. The RMSE compares term by term the actual difference between 
the predicted and measured value (Jacovides and Kontoyiannis, 1995). The smaller the value, the better the model performance. The MBE provides information on the level of under or over-estimation in model output, with a positive value indicating the average amount of over-estimation in the estimated values, and vice versa. Therefore, the RMSE and MBE must be used in combination for a complete and accurate evaluation of model performance. In addition, the Student $t$-test was used:

$\mathrm{t}=\frac{\overline{S_{l}}-\overline{O b}}{\sigma d}$

Where $S i$ and $\bar{O} b$ are the simulated and observed mean values, respectively, and $\boldsymbol{\sigma} d$ is the standard deviation of the difference between the means. In order for the model estimates to be statistically significant at the 1- $\alpha$ confidence level, the calculated $t$ value must be less than the critical $t$ value (determined from a standard statistical $t$-table). This validation showed no significant difference between the simulated and observed yields since the calculated $t$ values were lower than the critical $t$ value $(\mathrm{p}<0.01)$ for both rainfed and irrigated yields (Table 4). Good model performance was shown by the low RMSE values for both rainfed $\left(0.38 \mathrm{t} \mathrm{ha}^{-1}\right)$ and irrigated $\left(0.73 \mathrm{tha}^{-1}\right)$ yields, confirming that the calibrated model was suitable for simulating future rice yields.

\section{Results and Discussion}

\subsection{Climate impacts on rice yield}

Simulated yields $\left(\mathrm{t} \mathrm{ha}^{-1}\right)$ for the 'baseline' are summarised in Figure 6, shown as a 'box and whisker' plot for both rainfed and irrigated rice in the study area. The 'box' defines the upper $(25 \%)$ and lower (75\%) quartiles; the line shown in the middle of the box represents the median and the 'whiskers' indicate the 10th (lower) and 90th (upper) deciles. Any outliers are shown as individual points. The plot thus helps to understand the range, median and normality (and any skew) in the yield distribution. The long-term average yield for rainfed ( $c v$.Kilombero) rice $\left(4.75 \mathrm{t} \mathrm{ha}^{-1}\right)$ is higher than the irrigated $(c v$. Pussa 33) variety $\left(4.1 \mathrm{t} \mathrm{ha}^{-1}\right)$. However, Kilombero rice is grown during the wettest months when $>75 \%$ of annual rainfall occurs. In contrast, Pusa 33 rice is grown during the dry season and receives $<5 \%$ of total annual rainfall; hence irrigation is required to maintain productivity. At present, water availability is not a limiting factor in most years, so other management practices are likely to account for these 
observed differences. However, in recent years, low flows have restricted river water abstractions for irrigation, so although defined as being 'irrigated' in some years the irrigated yield data actually reflects partial (rather than full) irrigation due to some seasonal water resource constraints. Figure 6 also reflects the inter-annual variability since the planting and harvest dates, plant density (75 plants per $\left.\mathrm{m}^{2}\right)$, nitrogen applications (50 $\mathrm{kg} \mathrm{ha}^{-1}$ directly after transplanting and other $50 \mathrm{~kg} \mathrm{ha}^{-1} 30$ days later) and flooded irrigation depth $(50 \mathrm{~mm})$ were all kept constant. For the baseline, rainfed yield is, in probability terms, 'very likely' to fluctuate between 4.5 and $5.2 \mathrm{t} \mathrm{ha}^{-1}$ but 'less likely' to reach $3.5 \mathrm{t} \mathrm{ha}^{-1}$ or $5.8 \mathrm{t} \mathrm{ha} \mathrm{h}^{-1}$. For irrigated rice, the yield fluctuates around $4 \mathrm{t} / \mathrm{ha}$, but under extremes of climate could range between 3.0 and $5.5 \mathrm{tha}^{-1}$.

For each combination of GCM and emission scenario, 100 years synthetic weather data generated using the LARS-WG were used in CERES-Rice to simulate future yield (Figure 7). For all three GCMs an increase in yield is predicted for both rain-fed and irrigated production. Under a low (B1) emissions scenario, rainfed yield is projected to increase by $+8 \%$ with a range of +4 to $+11 \%$ whilst irrigated yields are projected to increase by $+9 \%$ with an inter-annual variation of between $+6 \%$ and $+11 \%$. However, under 'very unlikely' climate conditions, yields could be reduced by between $-7 \%$ and $-2 \%$ (Figure 7). Similarly, under the high (A2) emission scenario, rainfed yields are predicted to increase by $+5 \%( \pm 4 \%)$ and $+4 \%( \pm 3 \%)$ for irrigated rice. Rice yields in this part of Malawi could therefore drop by between $-6 \%$ to $-10 \%$ compared to the baseline but with a low level of probability. These yield projections are consistent with Lobell et al. (2008) who used statistical crop models and climate projections from $20 \mathrm{GCMs}$ to analyse climate risks in 12 food-insecure regions. Lobell et al. (2008) reported that an increase of +4 to $+5 \%$ rice yield in South Africa and East Africa due to climate change by the 2030s was possible. However, a recent systematic review by Knox et al. (2012) reported that the scientific evidence for climate impacts on rice yield in Africa was inconclusive, since only a very limited number of observations $(n=5)$ exist, which were insufficient to conduct any detailed metaanalysis.

\subsection{Model sensitivity}

In climate impact assessments, crop model sensitivity plays an important role in understanding the relationships between input and output variables. In this study, the sensitivity of the CERES-Rice model to 
systematic changes in weather has been evaluated, by adjusting independently and in a step-wise manner the daily weather data for the baseline (1961-1990) to assess model sensitivity to changing values of temperature, solar radiation and $\mathrm{CO}_{2}$. These variables were chosen because they are key environmental factors that influence crop growth. The model was tested under an unconstrained management scheme in response to a range of $\pm 4^{\circ} \mathrm{C}$ for temperature, $-20 \%$ to $+30 \%$ changes in solar radiation and 330 to $660 \mathrm{ppm}$ for $\mathrm{CO}_{2}$ concentration.

Several studies report on a reduction in rice yield with an increase in temperature. However, the exact effect on yield depends on the temperature at a specific site in relation to critical temperatures at different growth stages (De Datta, 1981). Anthesis is when rice is most sensitive to high temperature. Matthews et al. (1997) reported that an increase in temperature above $35^{\circ} \mathrm{C}$ speeds up plant development but decreases the length of the grain filling period or maturity time, resulting in spikelet sterility and reduction in yields. In this study, maximum yield was observed when the daily mean temperature of the baseline decreased whilst higher temperatures significantly decreased rice productivity. Under rainfed conditions, the maximum yield increase $(+23 \%)$ was achieved with a decrease in daily temperature by $-3^{\circ} \mathrm{C}$ whilst yield improvements under irrigated conditions were relatively minor (Figure 8). However, further decreases in daily mean temperature start to negatively affect potential rice yield. The difference between rainfed and irrigated yield in response to temperature change is caused mainly by variety difference rather than by irrigation practices. The annual yield variability (vertical bars) depends on the weather conditions in each particular year. For example, an increase in temperature by $4{ }^{\circ} \mathrm{C}$ resulted in an average $35 \%$ yield reduction and high yield variability since the extremes under normal conditions become even more extreme with a change in average temperature (Figure 8). The analysis shows that an increase in daily mean temperature will result in a lower yield when all other variables remain unchanged.

Higher yield is observed under conditions of increased radiation for both rice varieties (Figure 9). An increase in radiation by $30 \%$ leads to an average +11 to $+13 \%$ yield increase. Similarly, a decrease in radiation by $-20 \%$ resulted in an -11 to $-13 \%$ yield reduction. This shows how solar radiation is a critical environmental factor influencing rice production. Generally, increases in $\mathrm{CO}_{2}$ concentration result in a yield increase under both rainfed and irrigated production (Figure 10). This is because most C3 plants, including rice, exhibit an increased rate of net photosynthesis under elevated $\mathrm{CO}_{2}$ concentrations. High 
$\mathrm{CO}_{2}$ concentrations also reduce the stomatal opening of plants thereby reducing transpiration per unit leaf area while enhancing photosynthesis, thus increasing yield and reducing water use. In this study, a doubling of $\mathrm{CO}_{2}$ atmospheric concentration resulted in a yield increase for rainfed rice of $+15 \%$ which is consistent Lal et al. (1998). The irrigated variety (Pusa 33) showed a better response to increases in $\mathrm{CO}_{2}$ concentration than rainfed rice (Figure 10).

\subsection{Methodological limitations}

The approaches used in this study have some limitations which need to be recognised. As with other crop models, CERES-Rice is used with a set of agronomic and management assumptions. For example, the impacts of weeds, pests and diseases on crop growth, development and final yield are all assumed to be optimally controlled. The damaging effects of catastrophic weather events and deteriorated soils are also excluded. These conditions would underestimate the negative effects of climate change on yield, particularly in this part of the world, where management controls are constrained by the availability and cost of agrochemicals. In CERES-Rice, the simulated planting and harvest dates were also fixed in each simulation year regardless of whether ambient conditions were suitable. In reality, planting dates depend on the availability of sufficient water in the soil and rainfall. Similarly, harvest dates depend on maturity of the crop; any delay in harvest leads to yield loss due to damage by pests. There is thus need to investigate the impacts of climate change on the cropping calendar and its effects on autonomous adaptation.

Modelling uncertainty has been addressed using the output from three GCM models. These were chosen for their contrasting projections of future rainfall for that locality. However, even though these cover a wide range of projections, they do not necessarily cover the entire range as other GCMs were not considered. Further work should consider other GCMs and emissions scenarios. In addition, the projected yields were based on the assumption that there will be favourable rainfall distribution throughout the growing season as the GCMs are not able to project occurrence of droughts and floods (Bachelet et al., 1994). In reality, rainfall distribution in eastern and southern Africa is associated with uncertainties such as droughts and floods due to inter-annual climate variability (Thornton et al., 2006). Consequently, rainfed rice might be subject to much higher variability than predicted here in this study. Notwithstanding these limitations, as a preliminary assessment of climate impacts on rice yield in Malawi this study represents an important and useful basis from which to develop more detailed investigations. 


\subsection{Adaptation responses}

Climate change is likely to exacerbate many of the challenges already facing farmers in Africa. As in other agricultural cropping systems, the key will be in adaptation, and securing the relevant skills, resources and knowledge to increase production efficiency, improve management and embrace new technology (Knox et al., 2010). The outputs from the crop modelling assumed unchanged farming practices in future, but in reality there will be some degree of autonomous even if not planned adaptation. Farm level adaptation options could include adjusting planting dates necessary for more efficient utilization of water (Singh $e t$ al., 1994). Planting early-maturing varieties under rainfed conditions will also reduce cropping duration and provide an opportunity to plant early for an irrigated crop. This will help to make use of available water resources before minimum flows are reached.

In this study, the impact of climate change on the length of the growing season has been assessed by comparing the growing degree days (GDD) of the baseline period with those under a changed future climate. This has been made under the assumption that the future planting date of both rice varieties will remain the same as current date assumed for the baseline. As climate warms, the rice plant grows faster and matures earlier as long as it is not subject to extreme temperatures or shortages in water availability. For example, in the future, the Kilombero variety was projected to mature between 14 and 18 days earlier under the SRB1 and SRA2 emissions scenarios, respectively. For Pusa, the length of the growing season to reach maturity could be reduced by between 11 and 15 days under the same SRB1 and SRA2 emissions, respectively.

Changes in the timing and duration of agronomic practices such as fertilizer application, weed control, pest and disease management would also help maximise grain yield (Singh et al., 1994). Changes in soil tillage including conservation tillage to minimise soil erosion and improve the water holding capacity of the soil (Dinar et al., 2008) might become more widespread. There may also be greater uptake of land levelling to provide more efficient flooded irrigation management as well as reducing the area under irrigation command to match available resources (Dinar et al., 2008). Malawian rice production could also adapt its production towards a System of Rice Intensification (SRI) being widely promoted in irrigation schemes across East Africa (e.g. Kenya and Tanzania). However, although changes in cultivation practices including using younger seedling transplants, lower planting densities, and changes in irrigation timing 
have reportedly led to increased rice yields, reduced water use and greater environmental benefits (Kassam, and Brammer, 2013) there is much debate over the real benefits of SRI (Sumberg et al., 2013).

Finally, investing in more efficient application technologies for irrigated production could reduce some of the water inefficiencies (deep drainage, runoff) often associated with surface (flood) irrigation in rice, especially on soils with high infiltration rates. Short term coping and strategic longer terms plans will be needed by government agencies and stakeholders to assist farmers in these regions in identifying and then implementing appropriate and affordable adaptation responses. The challenge lies in reconciling the societal and economic benefits of such interventions to buffer farmers against a changing and uncertain climate, within the economic constraints facing countries such as Malawi in dealing with persisting food insecurity and land management issues.

It could be argued that more attention should be focussed on irrigated rice production due to the importance of irrigation in buffering the impact of the dry spells and rainfall seasonality. Irrigated rice plays major role in the socio-economic development of rural communities. However, the major threat to irrigation development is the potential reduction in future resource availability especially from perennial rivers. In Malawi, the rivers in central and northern regions are projected to experience significant decreases in flow during the dry season (June to October) by the 2050s (Kumambala, 2010). This this will inevitably result in greater stress on resource availability within those river basins. The three rice schemes considered in this study are linked to the Lufira, Hara and Wovwe Rivers which are all among those most likely to be affected, thus posing a major threat to the future sustainability of these rice schemes.

\section{Conclusions}

A preliminary assessment of the impacts of climate change on rain-fed and irrigated rice yield in Malawi has been completed using the CERES-Rice crop model, calibrated and validated using 10 years field data. Although relatively small increases in average yield were projected, there was much larger uncertainty due to the use of different GCMs and emission scenario. Farmer responses to cope with the projected changes in climate were outlined and are likely to include both autonomous and planned adaptation strategies. Autonomous responses include modifying planting dates and cropping calendars to maximise crop growth and available moisture in the soil; more strategic planned measures may include increased use of on-farm 
water conservation measures to support rainfed production, and the use of modern land levelling techniques to improve water efficiency in rice schemes that are dependent on surface irrigation. The study provides a valuable contribution to the limited literature on climate impacts in East Africa and should support government agencies and NGOs is implementing development programmes to promote sustainable agricultural development.

\section{Acknowledgement}

The authors acknowledge the Government of Malawi for financial support and Karonga District

Agricultural Development Office for provision of field datasets. Climate data were provided by the

Department of Climate Change and Meteorological Services in Malawi.

\section{References}

Aggarwal, P.K., Mall, R.K. (2002). Climate change and rice yields in diverse agro-environments of India. Effect of uncertainties in scenarios and crop models on impacts assessment. Climate Change 52: 331-343.

Bachelet, D. King, G.A. and Chaney, J. (1994). Climate change scenarios. In Modelling the impacts of climate change on rice production in Asia, ed. Matthews, R.B., Kropff, M.J., Bachelet, D., and van Laar, H.H. Cab International in association with the International Rice Research Institute, pp 67-83.

Boko, M., I. Niang, A. Nyong, C. Vogel, A. Githeko, M. Medany, B. Osman-Elasha, R. Tabo and P. Yanda, (2007): Africa. Climate Change 2007: Impacts, Adaptation and Vulnerability. Contribution of Working Group II to the $4^{\text {th }}$ Assessment Report of the Intergovernmental Panel on Climate Change, M.L. Parry, O.F. Canziani, J.P. Palutikof, P.J. van der Linden, C.E. Hanson, Camb University Press, 433-467.

Christensen, J.H., B. Hewitson, A. Busuioc, A. Chen, X. Gao, I. Held, R. Jones, R.K. Kolli, W.-T. Kwon, R. Laprise, V. Magaña Rueda, L. Mearns, C.G. Menéndez, J. Räisänen, A. Rinke, A. Sarr and P. Whetton, (2007). Regional Climate Projections. In: Climate Change 2007: The Physical Science Basis. Contribution of Working Group I to the Fourth Assessment Report of the Intergovernmental Panel on Climate Change [Solomon, S., D. Qin, M. Manning, Z. Chen, M. Marquis, K.B. Averyt, M. Tignor and H.L. Miller (eds.)]. Cambridge University Press, Cambridge, United Kingdom and New York, NY, USA.

Cooper, P.J.M., Dimes, J., Rao, K.P.C., Shapiro, B., Shiferaw, B., Twomlow, S (2008) Coping better with current climatic variability in the rain-fed farming systems of sub-Saharan Africa: An essential first step in adapting to future climate change? Agriculture, Ecosystems and Environment 126 (1-2): 24-35.

DADO Karonga (2010). Baseline soil and agro-climate data for Hara, Lufira and Wovwe irrigation schemes. Karonga ADD, Ministry of Agriculture and Food Security, Malawi. . Information provided through consultation.

De Datta, S.K. (1981). Principles and practices of rice production. A Wiley-Interscience Publication. John Wiley and Sons. Singapore.

Dinar, A., Hassan, R., Mendelsohn, R., Benhin, J., and others. (2008). Climate change and agriculture in Africa. Impact assessment and adaptation strategies. Earthscan. London.

FAO STAT (2012). http://faostat.fao.org/

FAO/IIASA,(2010). Global Agro-ecological Zones (GAEZ v3.0). FAO, Rome, Italy and IIASA, Laxenburg, Austria.

Fischer, G., Shah, M., Tubiello, F.N. and van Velhuizen, H. (2005). Socio-economic and climate change impacts on agriculture: an integrated assessment, 1990-2080. Philos. Trans. R. Soc. B 360: 2067-2083. 
Government of Malawi (GoM) (2008). The Agricultural Development Programme. Ministry of Agriculture and Food Security (MoAFS), Lilongwe, Malawi.

IPCC (2013). Data Distribution Centre .http://www.ipcc-data.org/ar4/gcm_data.html. Last viewed on the $1^{\text {st }}$ November 2013.

Jacovides, C.P., and Kontoyiannis, H. (1995). Statistical procedures for the evaluation of evepotranspiration computing models. Agricultural Water Management 27: 365-371.

Jones, J.W., Hoogenboom, G., Portera, C.H., Boote, K.J., Batchelor, W.D., Hunt, L.A., Wilkens, P.W., Singh, U., Gijsman, A.J. and Ritchie, J.T. (2003). The DSSAT cropping system model. European Journal of Agronomy 18, 235-265.

Kanyika, W.A., Saka, A.R., and Mviha, P. (2007). Response of Nunkire rice variety to fertilizer nitrogen application and plant spacing under irrigated conditions in Malawi. Malawi Journal of Agricultural Sciences, Vol. 3.

Kassam, A., and Brammer H (2013) Combining sustainable agricultural production with economic and environmental benefits The Geographical Journal 179(1): 11-18.

Knox, J.W., Rodriguez Diaz, J.A., Nixon, D.J. and Mkhwanazi, M. (2010). A preliminary assessment of climate change impacts on sugarcane in Swaziland. Agricultural Systems 103: 63-72.

Knox, J.W., Hess, T.M., Daccache, A. and Wheeler, T. (2012). Climate change impacts on crop productivity in Africa and South Asia. Environmental Research Letters 7034032.

Kumambala, P. G. (2010). Sustainability of water resources development for Malawi with particular emphasis on north and central Malawi. PhD Thesis. University of Glasgow, UK.

Lal, M., Singh, K.K., Rathore, L.S., Srinivasan, G. and Saseendran, S.A. (1998). Vulnerability of rice and wheat yields in NW India to future changes in climate. Agricultural and Forest Meteorology 89: 101-114.

Lobell, D. B., Burke, M.B., Tebaldi, C., Mastrandrea , M.D., Falcon, W.P. and Naylor, R.L. (2008) Prioritizing Climate Change Adaptation Needs for Food Security in 2030, Science 319.

Matthews, R.B., Kropff, M.J., Horie, T. and Bachelet, D. (1997). Simulating the impact of climate change on rice production in Asia and evaluating options for adaptation. Agricultural Systems 54: 399-425.

Meehl, G.A., Stocker, T.F., Collins, W.D., Friedlingstein, P., Gaye, A.T., Gregory, J.M., Kitoh, A., Knutti, R., Murphy, J.M., Noda, A., Raper, S.C.B., Watterson, I.G., Weaver, A.J., and Zhao, Z. (2007). Global Climate Projections. In: Solomon, S., Qin, D., Manning, M.,Chen, Z., Marquis, M., Averyt, K.B., Tignor, M., Miller, H.L. (Eds.), Climate Change 2007: The Physical Science Basis. Contribution of Working Group I to the Fourth Assessment Report of the Intergovernmental Panel on Climate Change. Cambridge University Press, Cambridge, United Kingdom and New York, NY, USA.

Mzengeza, T. (2010) Genetic Studies of Grain and Morphological Traits in Early Generation Crosses of Malawi Rice (Oryza sativa L.) Landraces and NERICA Varieties. PhD Thesis. University of KwaZuluNatal, South Africa.

Nakicenovic, N., Alcamo, J., Davis, G., de Vries, B., Fenhann, J., Gaffin, S., Gregory, K., Grübler, A., Jung, T.Y., Kram, T., La Rovere, E.L., Michaelis, L., Mori, S., Morita, T., Pepper, W., Pitcher, H., Price, L., Raihi, K., Roehrl, A., Rogner, H., Sankovski, A., Schlesinger, M., Shukla, P., Smith, S., Swart, R., van Rooijen, S., Victor, N., Dadi, Z., (2000). IPCC Special Report on Emissions Scenarios. Cambridge University Press, Netherlands.

Ritchie, J.T., Alocija, E.C., Singh, U. and Uehara, G. (1986). IBSNAT and CERES-Rice model. A research paper presented at the international workshop on "The Impact of Weather Parameters on Growth and Yield of Rice" held on 7-10 Apr 1986 in Los Banos, Philippines.

Semenov, M.A., and Stratonovitch, P. (2010). Use of multi-model ensembles from global climate models for assessment of climate change impacts. Climate Research 41: 1-14.

Singh, U., Ritchie, J.T., and Godwin, D.C. (1993). A user guide to CERES-Rice V 2.10. International Fertilizer Development Center, Muscle Shoals, AL. 
Sié, M., Sanni, K., Futakuchi, K., Manneh, B., Mandé, S., Vodouhé, R., and Traoré, K (2012). Towards a rational use of African rice (Oryza glaberrima Steud.) for breeding in Sub-Saharan Africa. Genes, Genomes and Genomics 6 (1): 1-7. Global Science Books.

Singh, S., Rajan, A., Ibrahim, Y.B., and Sulaiman, W.H. (1994). Rice production in Malaysia under current and future climates. In Modelling the impacts of climate change on rice production in Asia, ed. Matthews, R.B., Kropff, M.J., Bachelet, D., and van Laar, H.H. Cab International in association with the International Rice Research Institute. pp 183-197.

Sistani, K.R., Reddy, K.C., Kanyika, W. and Savant, N.K. (1998). Integration of Rice Crop Residue into Sustainable Rice Production System. Journal of Plant Nutrition 21: 1855-1866.

Slingo, J.M., Challinor, A.J., Hoskins, B.J. and Wheeler, T.R. (2005). Introduction: Food crops in a changing climate. Philosophical Transactions of the Royal Society B. 360: 1983-1989.

Sumberg, J., Andersson, J., Giller, K., Thompson, J (2013) Response to combining sustainable agricultural production with economic and environmental benefits The Geographical Journal 179(2): 183-185.

Thornton, P.T., Jones, P.G., Owiyo T., Kruska R.L., Herrero M., Kristjanson P., Notenbaert A., Bekele N and Omolo A, with contributions from Orindi V, Otiende B, Ochieng A, Bhadwal S, Anantram K, Nair S, Kumar V and Kulkar U (2006). Mapping climate vulnerability and poverty in Africa. Report to the Department for International Development, ILRI, PO Box 30709, Nairobi 00100, Kenya. Pp 171.

Thornton, P.T., Jones, P.G., Alagarswamy, G. and Andresen, J. (2009). Spatial variation of crop yield response to climate change in East Africa. Global Environmental Change 19: 54-65.

Wheeler, T. and Kay, M. (2010) Food crop production, water and climate change in the developing world. Outlook on Agriculture, 39(4): 239-243.

Yao, F., Xu, Y., Lin, E., Yokozawa, M. and Zhang, J. (2007). Assessing the impact of climate change on rice yields in the main rice area of China. Climate Change 80: 395-409. 
Figure 1 Spatial distribution of rice production (irrigated and rainfed) in Malawi relative to the study area (Source: FAO/IIASA, 2010).

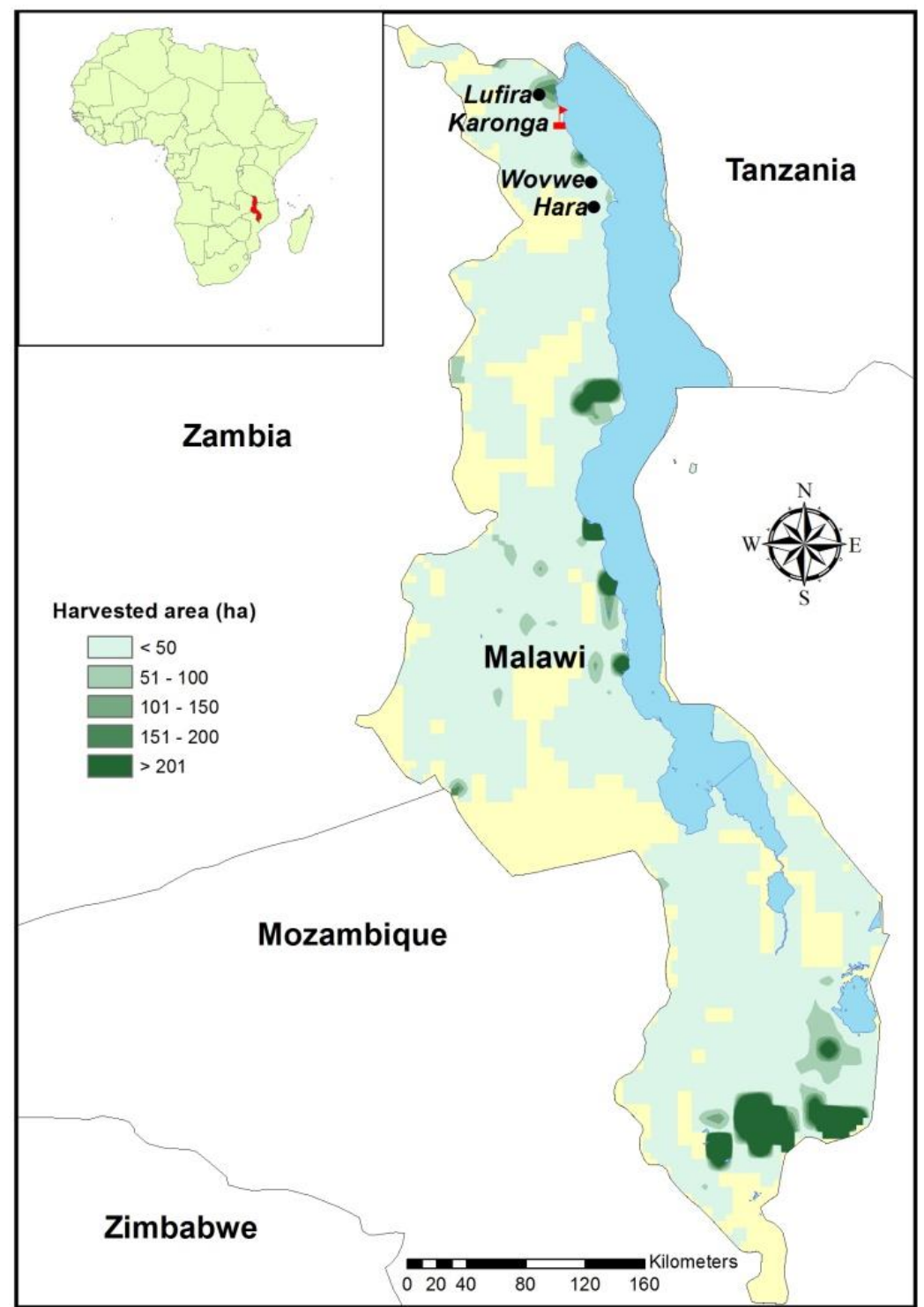


Figure 2 Long term average (1961-1990) rainfall and temperature (a) and reference evapotranspiration (ETo) (b) at Karonga (Malawi). The typical growing seasons for rainfed ( $c v$. Kilombero) and irrigated (cv. Pusa 33) rice are highlighted.

(a) Rainfall and temperature

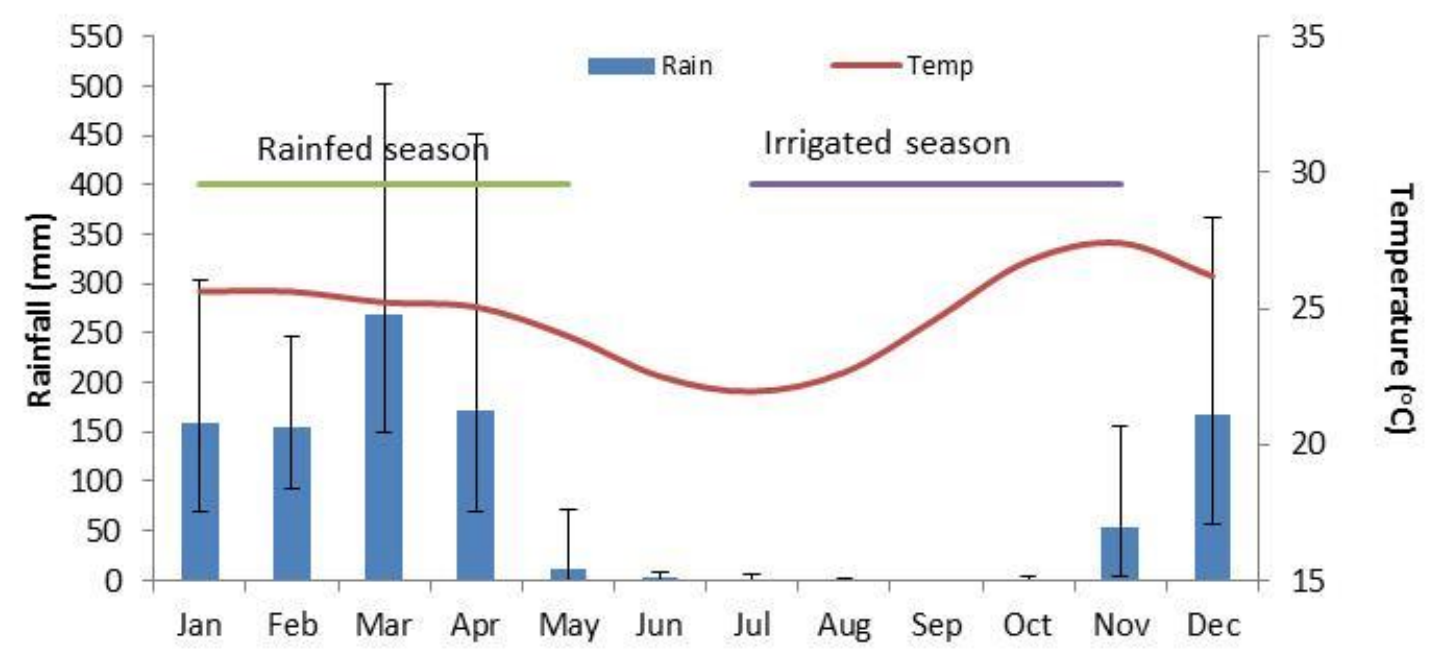

(b) Reference evapotranspiration (ETo)

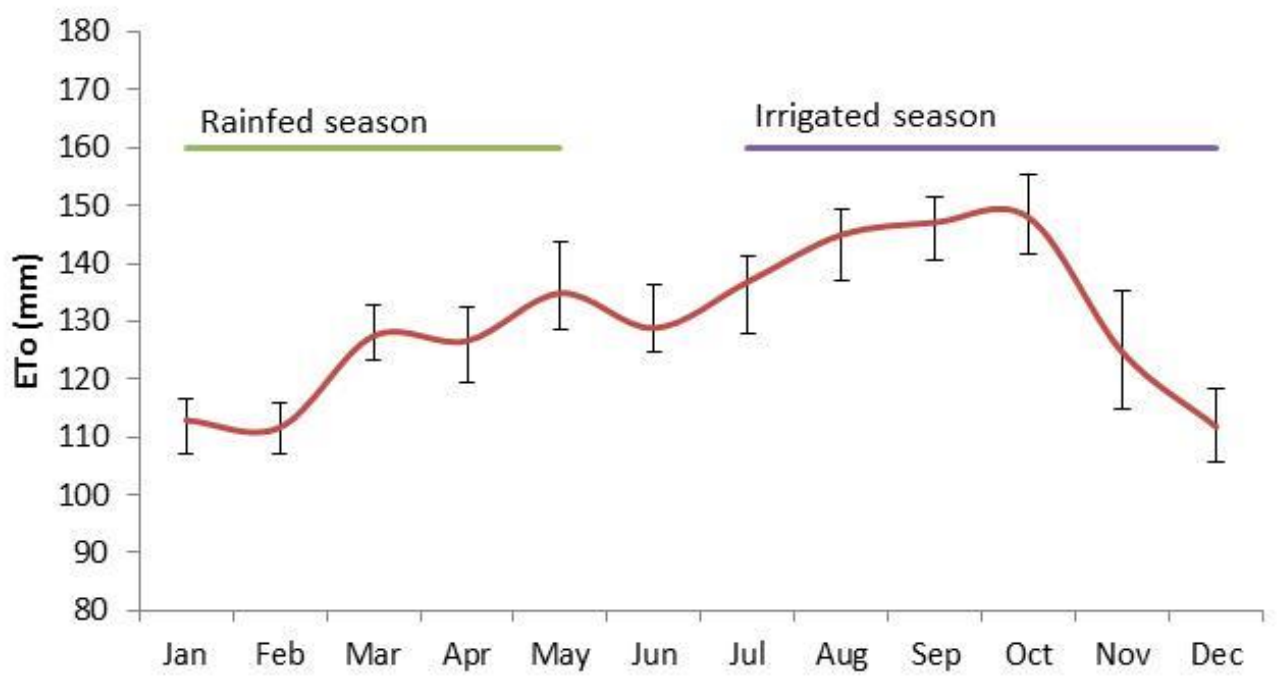


Figure 3 Projected changes in mean rainfall $(\mathrm{mm})$ and temperature (degree $\mathrm{C}$ ) for three GCMs (HADCM3, INCM3 and IPCM4) under the B1 and A2 emission scenarios. Error bars represent the minimum and maximum projected changes.

(a) Precipitation

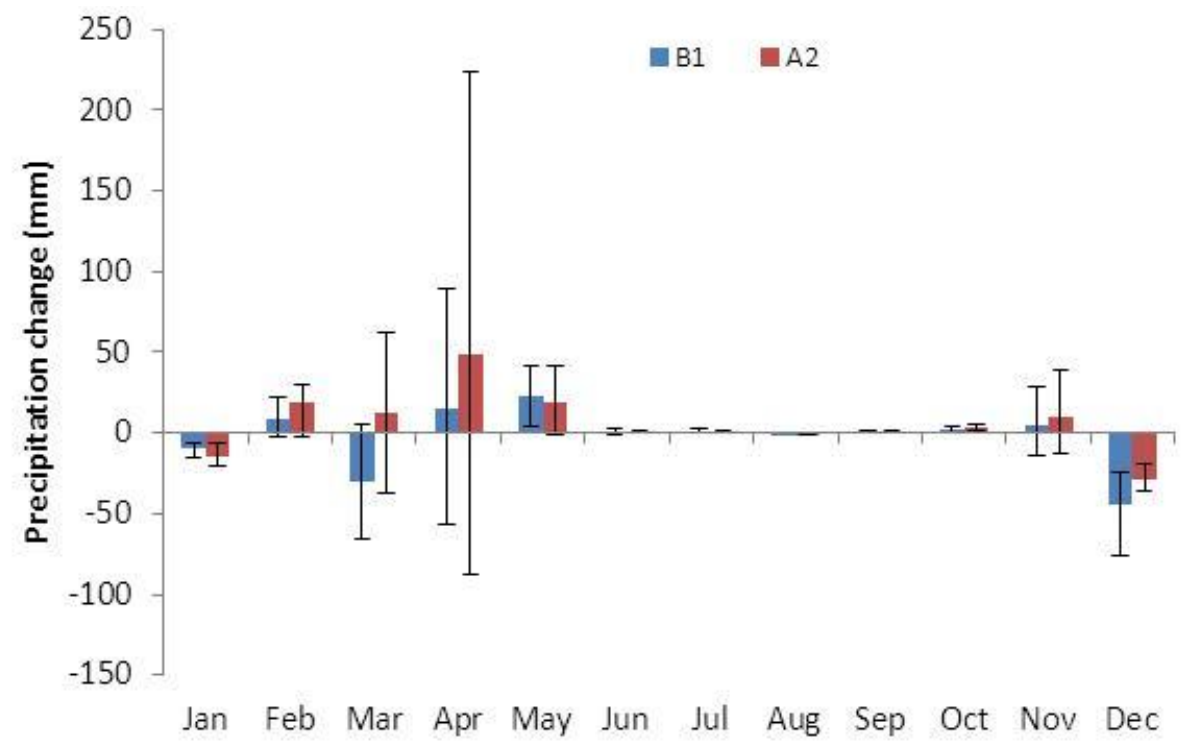

(b) Temperature

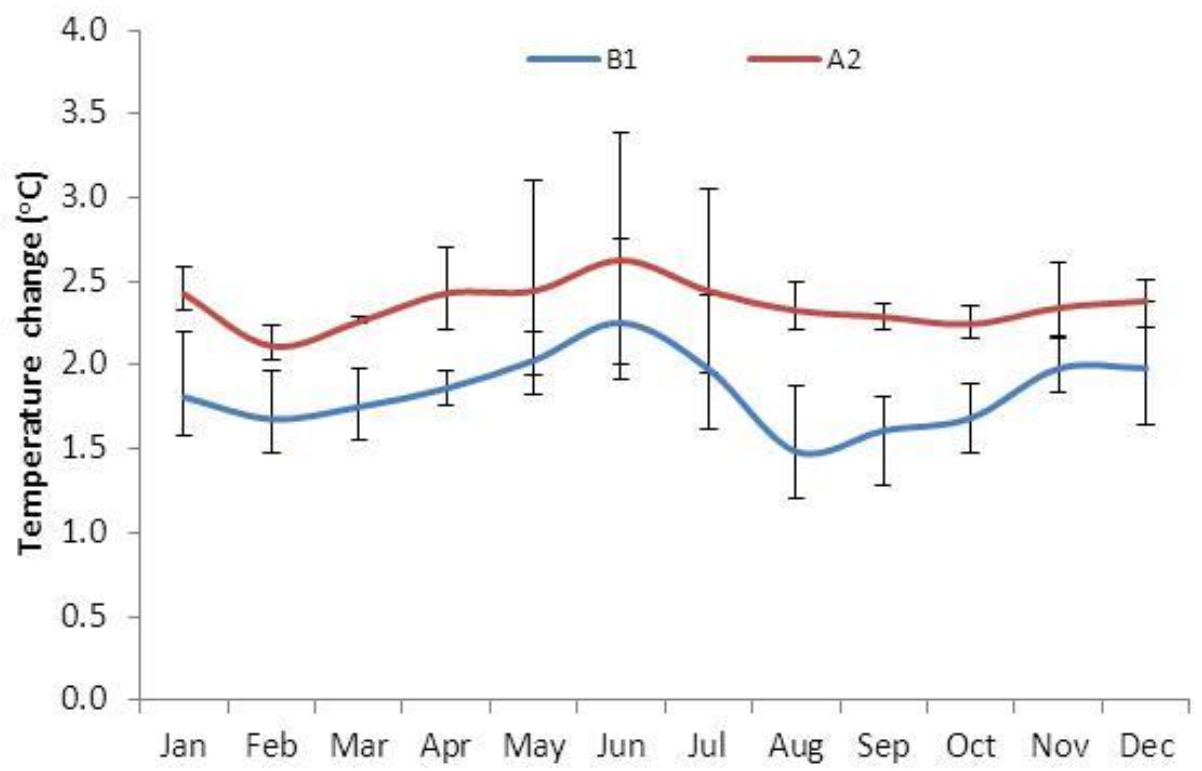


Figure 4 Observed yield $\left(\mathrm{t} \mathrm{ha}^{-1}\right)$ under rainfed (a) and irrigated (b) conditions at the three irrigation schemes.

(a) Rainfed rice

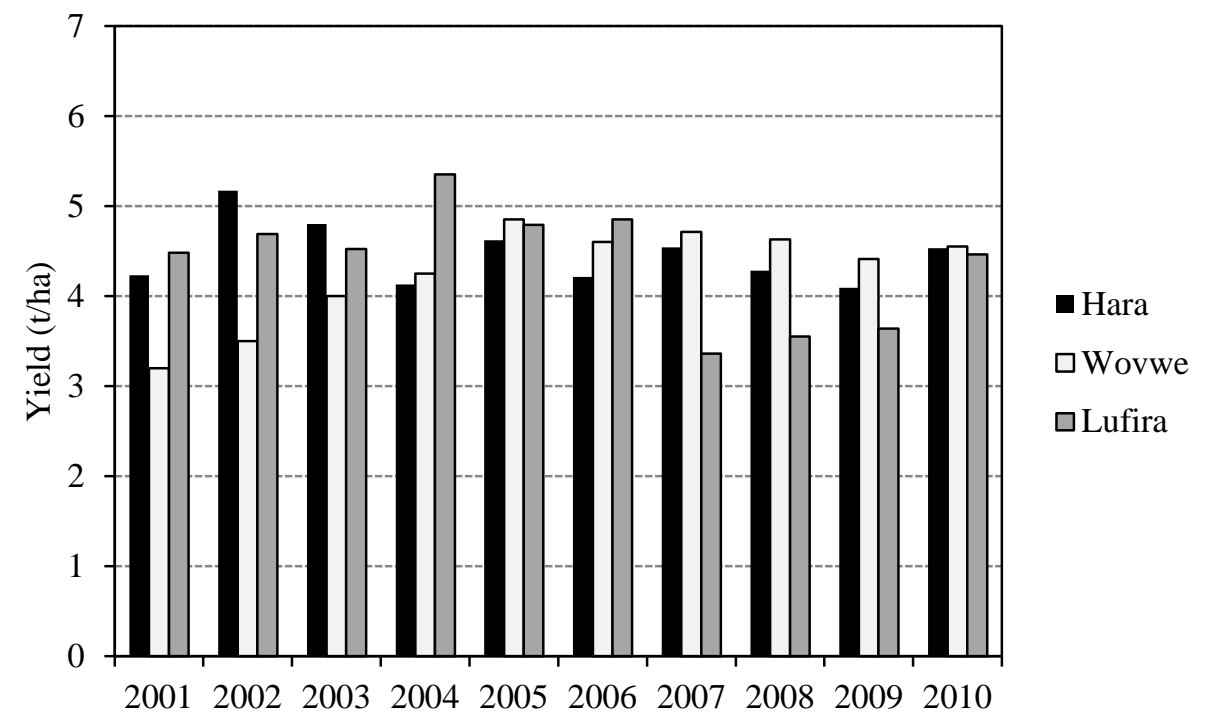

(b) Irrigated rice

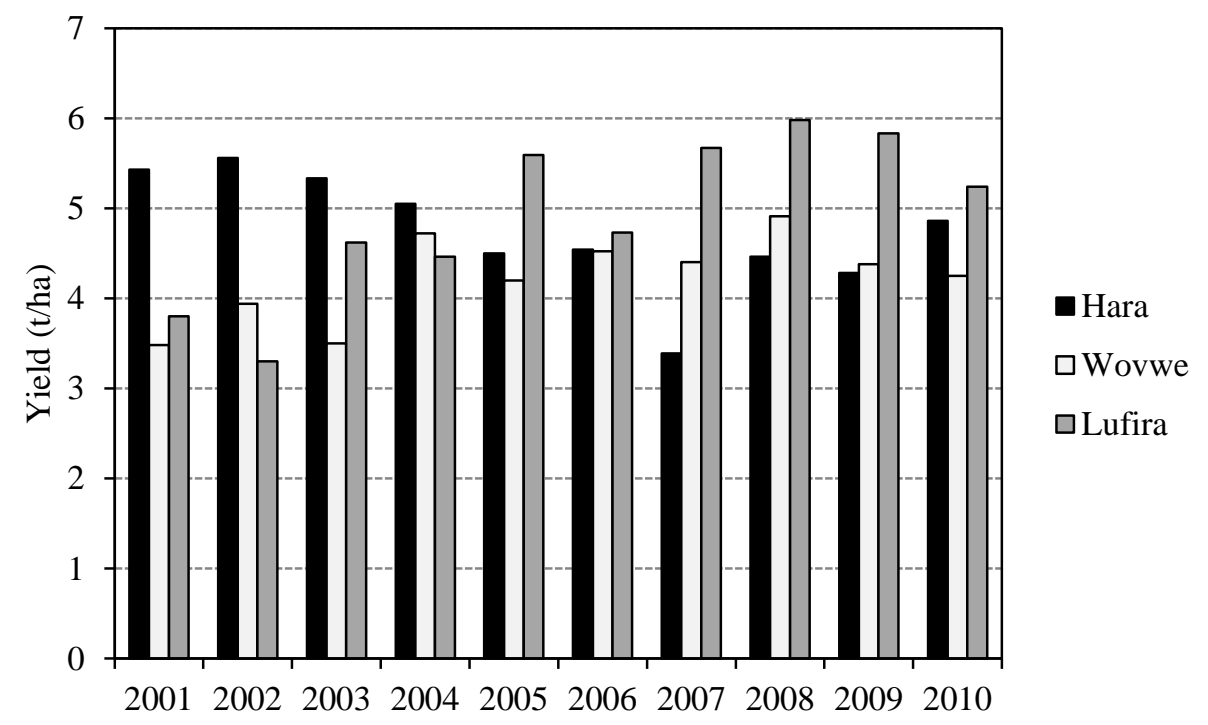


Figure 5 Linear correlations between observed rice yield $\left(\mathrm{t} \mathrm{ha} \mathrm{H}^{-1}\right)$ and CERES-Rice model simulated yield under (a) rainfed and (b) irrigated conditions.

(a) Rainfed rice

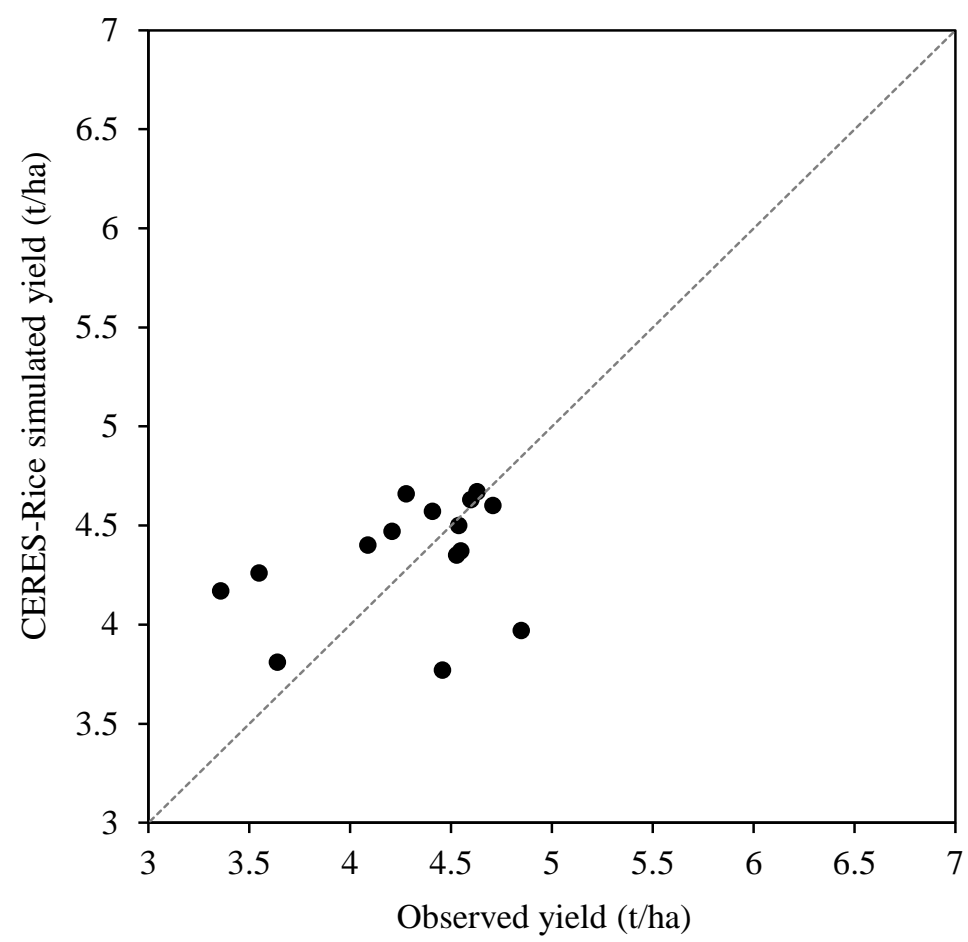

(b) Irrigated rice

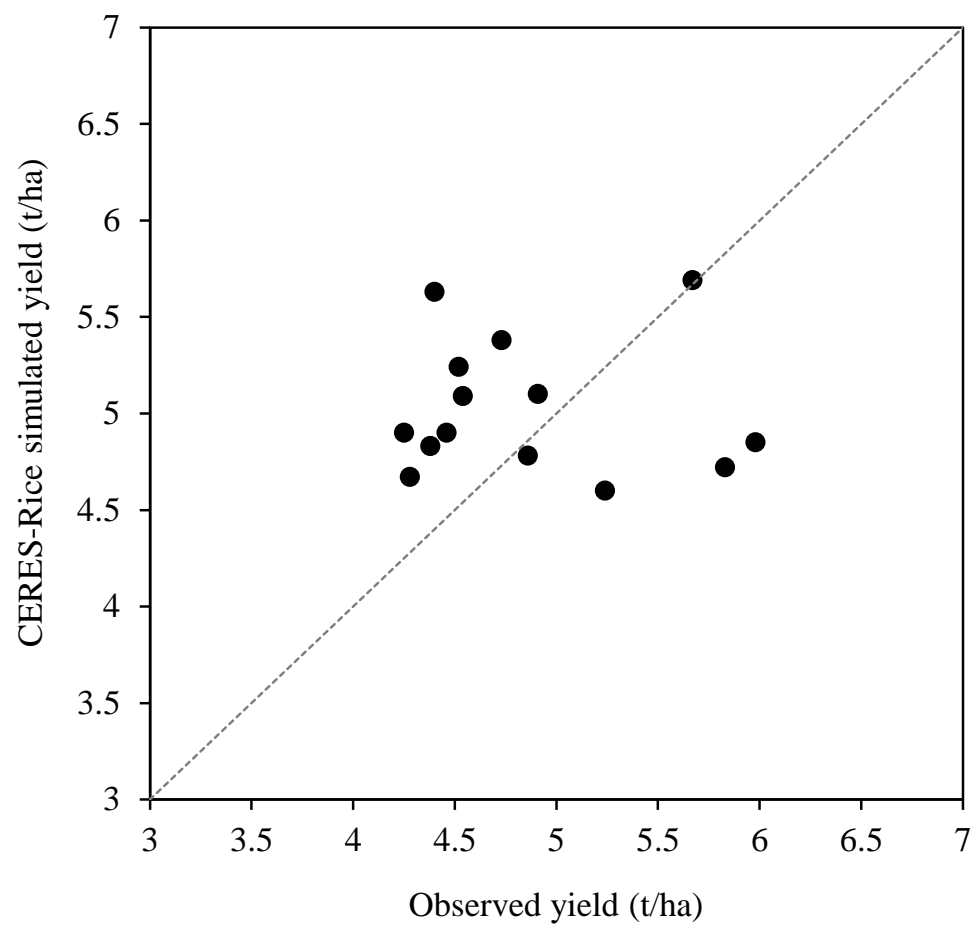


Figure 6 Simulated yield under the baseline (1961-1990) climatic conditions for rain-fed (cv. Kilombero) and irrigated rice (cv. Pussa 33) in the study area.

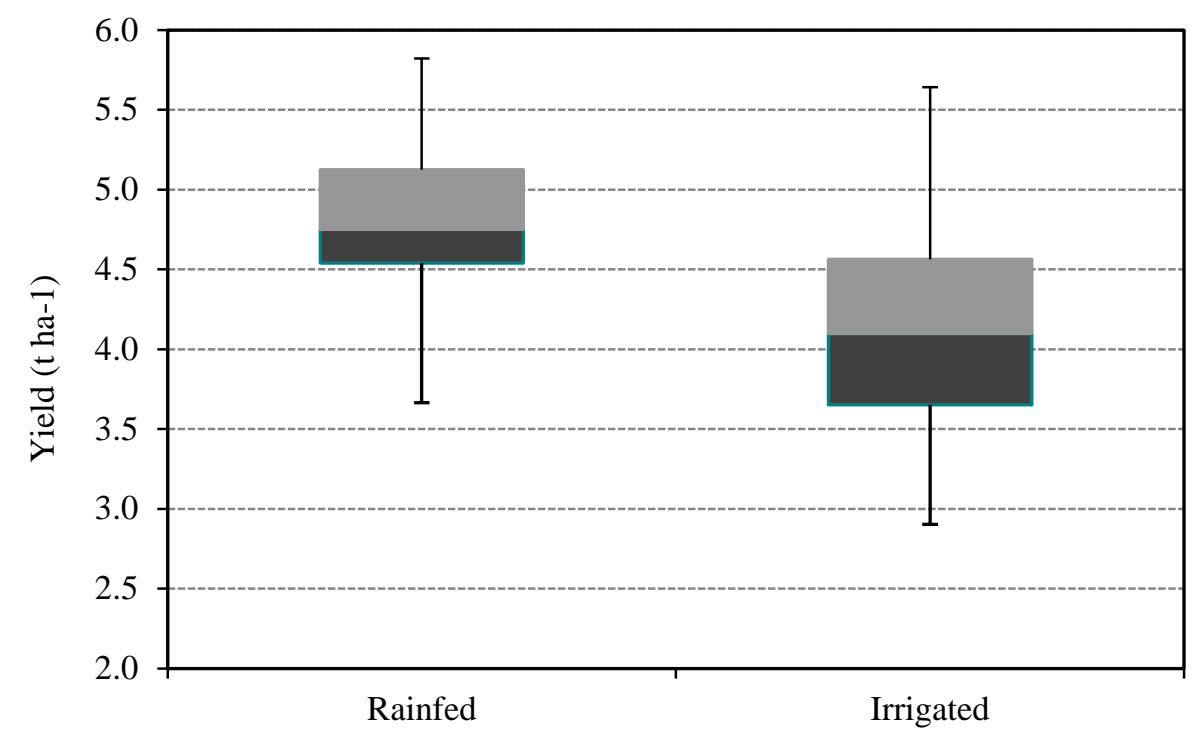

Figure 7 Projected yield changes (\%) in rainfed (cv. Kilombero) and irrigated (cv. Pussa 33) rice for the 2050s, using three GCMs and two emission scenarios.

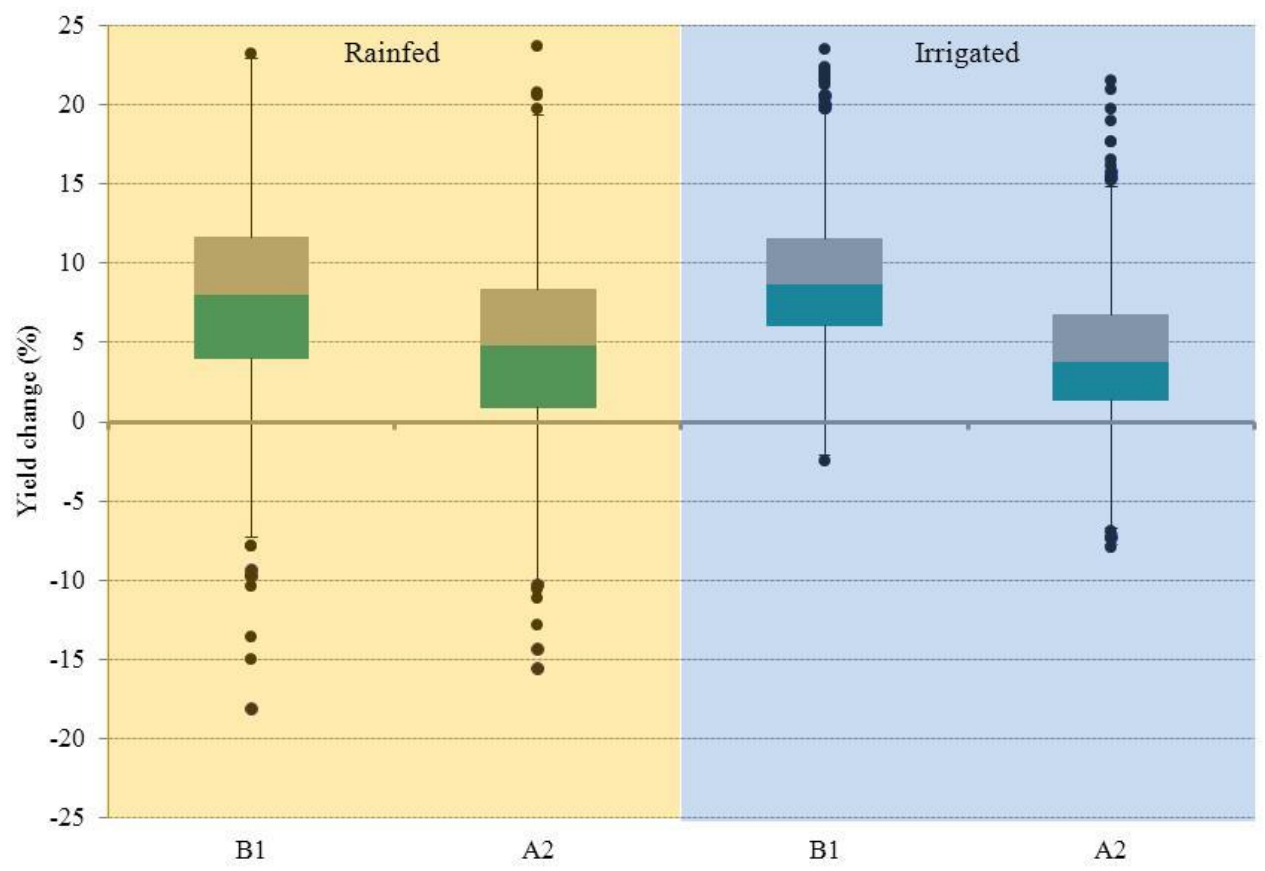


Figure 8 Sensitivity of CERES-Rice simulated yield to changes in temperature for rainfed (a) and irrigated rice. Vertical bars represent the inter-annual variation.
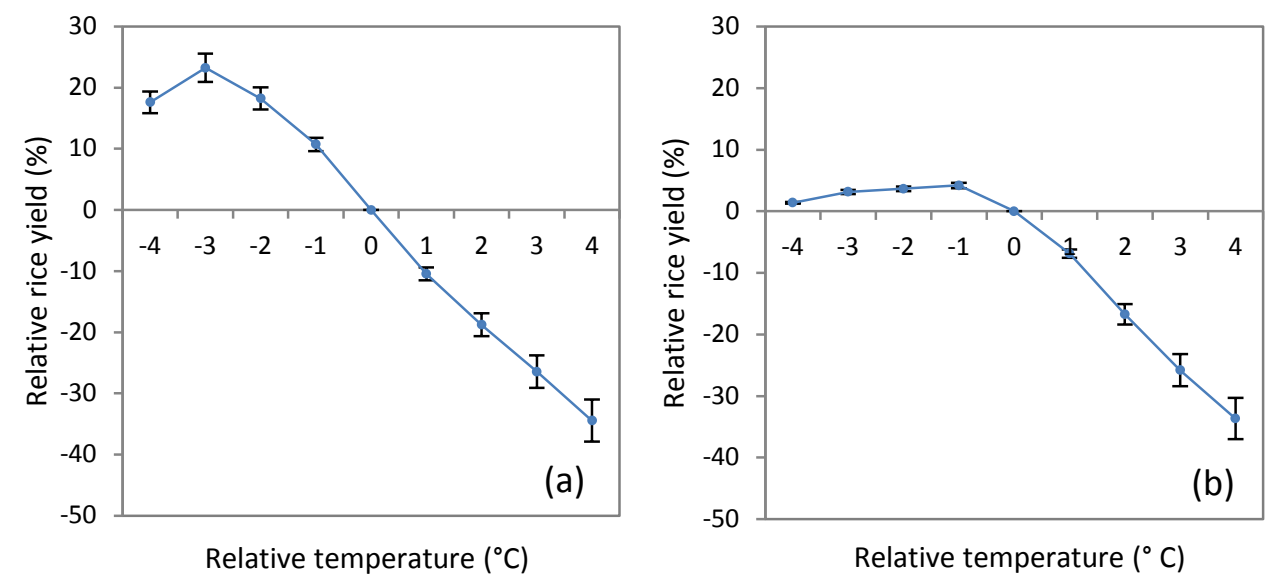

Figure 9 Sensitivity of CERES-Rice simulated yield to changes in radiation for rainfed (a) and irrigated (b) rice. Vertical bars represent the inter-annual variation.
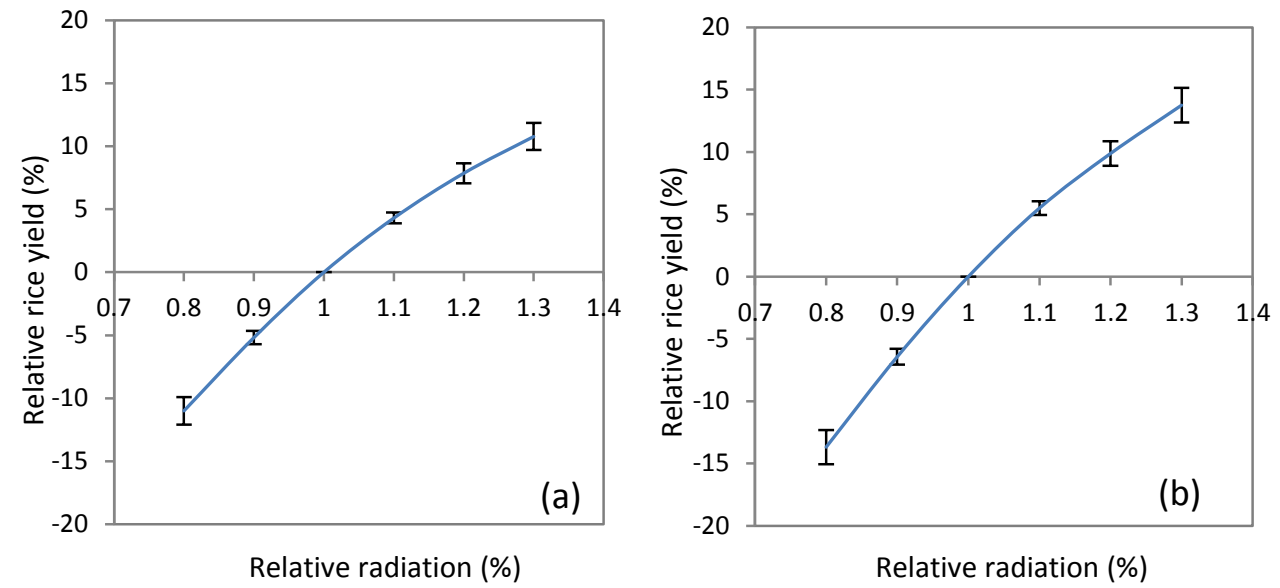

Figure 10 Sensitivity of CERES-Rice simulated changes in atmospheric $\mathrm{CO}_{2}$ concentration for rainfed (a) and irrigated (b) rice. Vertical bars represent the inter-annual variation.
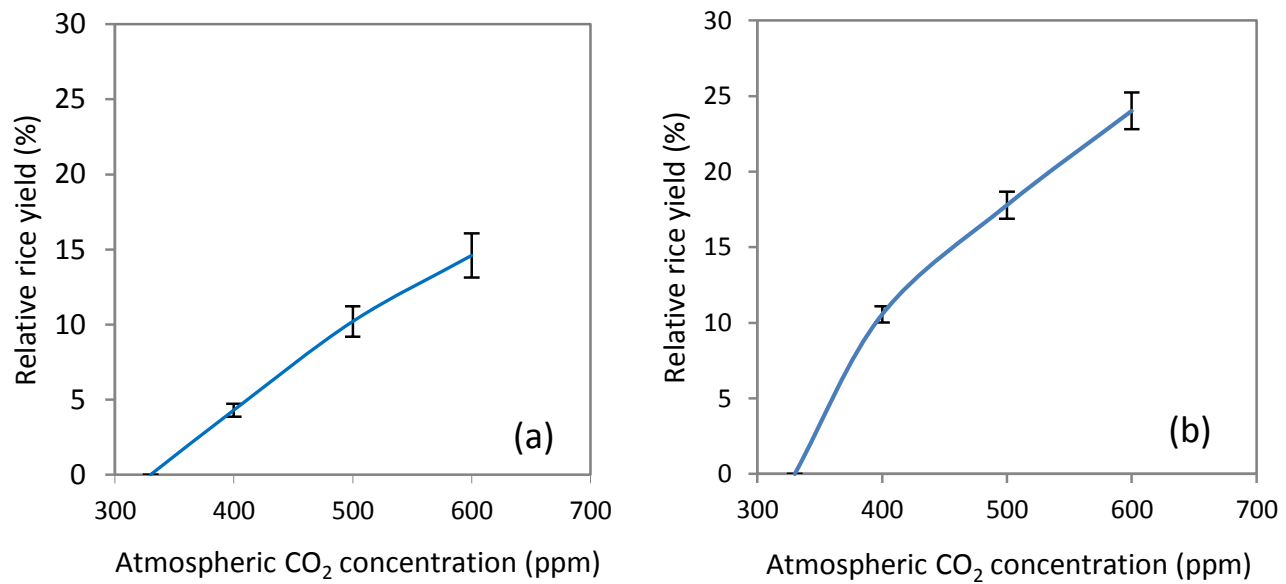
Table 1 Summary details and soil characteristics for each of the three rice schemes in Karonga District (Source DADO Karonga, 2010).

\begin{tabular}{lrrr}
\hline Characteristic & Hara & Lufira & Wovwe \\
\hline Latitude (S) & $10^{\circ} 29^{\prime}$ & $9^{\circ} 48^{\prime}$ & $10^{\circ} 20^{\prime}$ \\
Longitude (E) & $34^{\circ} 8^{\prime}$ & $33^{\circ} 48^{\prime}$ & $34^{\circ} 7^{\prime}$ \\
Elevation (m a.s.l.) & 540 & 550 & 545 \\
Command Area (ha) & 238 & 336 & 365 \\
Number of farmers & 631 & 1092 & 1216 \\
Average holding size (ha) & 0.38 & 0.31 & 0.30 \\
Distance from weather station (km) & 80 & 18 & 60 \\
\hline Texture & Clay loam & Clay loam & Clay loam \\
Sand (\%) & 20 & 30 & 25 \\
Silt (\%) & 35 & 33 & 35 \\
Clay (\%) & 45 & 37 & 40 \\
pH & 7.5 & 6.7 & 7.8 \\
Organic C (\%) & 1.73 & 1.82 & 1.76 \\
Total N (\%) & 0.60 & 0.70 & 0.55 \\
Available P (ppm) & 15 & 14 & 16 \\
CEC (cmol/kg) & 8.2 & 7.4 & 9 \\
\hline
\end{tabular}

Table 2 Agronomic and management parameters used for CERES-Rice model parameterisation (Source DADO Karonga, 2010).

\begin{tabular}{|c|c|c|}
\hline Parameter & Rainfed & Irrigated \\
\hline Cultivar & Kilombero & Pusa 33 \\
\hline Transplanting dates* & $1^{\text {st }} \mathrm{Jan}-15^{\text {th }} \mathrm{Feb}$ & $1^{\text {st }} \mathrm{Jul}-10^{\text {th }}$ Aug \\
\hline Row Spacing (cm) & 20 & 20 \\
\hline No of plants /hill & 4 & 4 \\
\hline No of plants $/ \mathrm{m}^{2}$ & 75 & 75 \\
\hline Transplanting age (days) & 30 & 30 \\
\hline Planting depth $(\mathrm{cm})$ & 6 & 6 \\
\hline Planting method & Transplanted & Transplanted \\
\hline \multicolumn{3}{|l|}{ Fertilizer $(\mathrm{N})$ application $(\mathrm{kg} / \mathrm{ha})$} \\
\hline 1 day after transplanting & 50 & 50 \\
\hline 30 days after transplanting & 50 & 50 \\
\hline Flood irrigation schedule (constant depth , mm) & & 50 \\
\hline Harvesting date* & $31^{\text {st }}$ May & $30^{\text {th }} \mathrm{Nov}$ \\
\hline
\end{tabular}

* Indicative dates, vary depending on the weather 
Table 3 Derived genetic coefficients for rainfed and irrigated rice varieties used for CERES-Rice model parameterisation.

\begin{tabular}{llrr}
\hline Parameter & Unit & Rainfed (Kilombero) & Irrigated (Pusa 33) \\
\hline Juvenile phase coefficient (P1) & GDD $\left({ }^{\circ} \mathrm{C}\right)$ & 502 & 380 \\
Photoperiodism coefficient (P2R) & GDD $\left({ }^{\circ} \mathrm{C}\right)$ & 100 & 50 \\
Grain filling duration coefficient $(\mathrm{P} 5)$ & GDD $\left({ }^{\circ} \mathrm{C}\right)$ & 350 & 380 \\
Critical photoperiod (P2O) & hours & 12 & 12 \\
Spikelet number coefficient (G1) & - & 60 & 50 \\
Single grain weigh (G2) & $(\mathrm{g})$ & 0.0230 & 0.0240 \\
Tillering coefficient $(\mathrm{G} 3)$ & - & 1.00 & 1.1 \\
Temperature tolerance coefficient $(\mathrm{G} 4)$ & - & 1.10 & 1.12 \\
\hline
\end{tabular}

Table 4 CERES-Rice model validation statistics for rainfed ( $c v$. Kilombero) and irrigated ( $c v$. Pusa 33) rice varieties for the study area in Malawi.

\begin{tabular}{|c|c|c|}
\hline Statistic & Rain-fed (Kilombero) & Irrigated (Pusa 33) \\
\hline Number of samples $(n)$ & 13 & 14 \\
\hline Mean observed yield (t.ha $\left.{ }^{-1}\right)$ & 4.23 & 4.9 \\
\hline Mean simulated yield (t.ha $\left.{ }^{-1}\right)$ & 4.34 & 5.01 \\
\hline SD observed yield (t.ha $\left.{ }^{-1}\right)$ & 0.44 & 0.62 \\
\hline SD simulated yield $\left(\right.$ t.ha $\left.^{-1}\right)$ & 0.29 & 0.36 \\
\hline $\operatorname{MBE}($ t.ha-1) & 0.02 & 0.46 \\
\hline $\operatorname{RMSE}\left(\mathrm{t}_{\mathrm{H}} \mathrm{ha}^{-1}\right)$ & 0.38 & 0.73 \\
\hline t statistic & 0.07 & 2.29 \\
\hline tcrit @99\% & 3.77 & 3.48 \\
\hline
\end{tabular}

